\title{
O)
}

AIAA 2000-3286

A REGENERATIVELY COOLED THRUST CHAMBER

FOR THE FASTRAC ENGINE

Kendall K. Brown and Dave Sparks

NASA Marshall Space Flight Center

Huntsville, AL

Gordon Woodcock

Space America, Inc.

Huntsville, AL

$36^{\text {th }}$ AIAA/ASME/SAE/ASEE Joint Propulsion Conference 16-19 July 2000

Huntsville, Alabama

Tor nermission to copy or to republish. contact the American Institute of Aeronautics and Astronautics, 1801 Alexander Bell Drive, Suite 500, Reston, VA, 20190-4344. 
AIAA-2000-3286

\title{
A REGENERATIVELY COOLED THRUST CHAMBER FOR THE FASTRAC ENGINE
}

\author{
Kendall K. Brown* and Dave Sparkst \\ Space Transportation Directorate \\ NASA/Marshall Space Flight Center, AL 35812 \\ Gordon R. Woodcock $\div$ \\ Space America. Inc. \\ Huntsville. Al 35824
}

\begin{abstract}
This paper presents the development of a low-cost, regeneratively-cooled thrust chamber for the Fastrac engine. The ehamber was labricated using hydraformed copper tubing to torm the coolint facket and wrapped with a tiber reinforced polvmer comnosite materal to form a structurat jacket. The thrust chamer design and fabrication approach was hased upon space America. Inc.'s 12.000 lb regeneratively-cololed L.OX/kerosene rocket ungine. Fabrication "1 regeneratively cooled thrust chambers by tatowatl

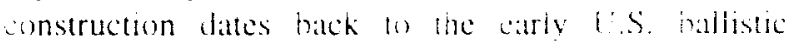

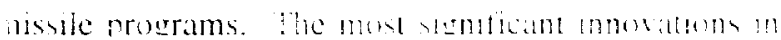
his design wals the development of a how-cost process che labrication from copper lubing anckel alloy was the usual practicel and use ol granhite eomposite acrwran as the pressure contanment. when gedis an cossty labricated. lightweight pressure jacket around the opper lubes. A reseneratively-enoled reusanle thruse

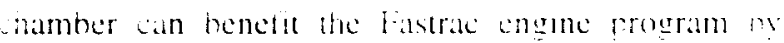

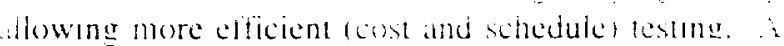
roof-ot-concept test articie has heen latrecited and wh be tested at Marshall Space thisht Center no the late Summer or Fall of 2000 .

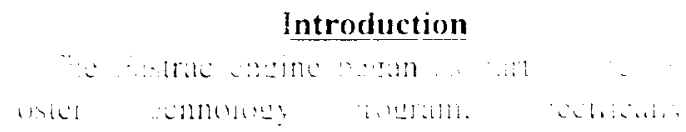

lemonstrate that off-the-shet products and commercial practices could he used to develop low-cost rocket ungines. Initially. the Fastrac engine was intended tor a sround launched expendable booster, but early in the

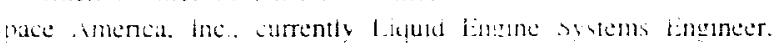
$\checkmark A S A / M S F C$. Senior Member.

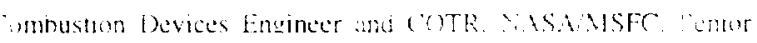
Nernber

Chief Engineer. Senior Member.

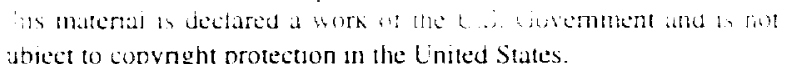

$\overline{0}$
\end{abstract}

design cycle it was chosen as the propulsion system for the X-34 high speed research vehicle. Since moving into the flight development stage. the engine has been e-designated the $\mathrm{MC}-1$.

Space America. Inc. (SAI) submitted a proposal inder NASA Research Announcement $8-21$. eycle 2 to welop a regeneratwety-cooled thrust chamber for the mistrac engine. The thrust chamber would be based on the design and fabrication processes demonstrated in $S \mathrm{Al}: 12.000) \mathrm{b}$, thrust $(12 \mathrm{~K})$. regeneratively-cooled, IOX/kerosene thrust chamber.

I regeneratively-conicd thrust chamber could encit the fastrac neme progran hy providing a cusabie inrust thamber. thus allowing more cost aficient cestune and operation. This paper will discuss the desien and fabricatton of the rroof-of-concept test artele and the est program that whi he conducted with the chamber.

\section{sesuach ()hjectues}

The oblectlve uf the contralet wals 10 evolve the thricaton anproacines ased by sill in the construction a the $\mathrm{i} 2 \mathrm{~K}$ thrust cinamber (6) a mgher fidelity unit which could undergo hot-fire testing with the Fastrac man infecor. Specifically, the research objectives are the bllowing:

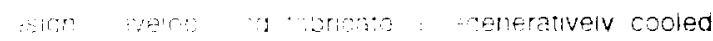

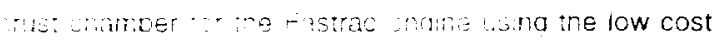

$$
\begin{aligned}
& \text { egeneratively soled thrust chamber methodology }
\end{aligned}
$$

- Develop conceptual layouts for integrating a regeneratively cooled thrust chamber into the Fastrac engine assemblv. with specific application to integration of

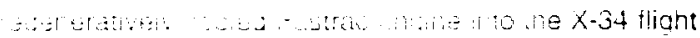
est program.

- Jrovide a proof-of-concept test article to MSFC for a 3est series in $T S: 16$. The test article will be tested at the same operating conditions as the current thrust chamber ussembly testing. Thermal data will be obtained to easure the cuik coolant temperature increase and the imperature at the coolant tube/composite jacket 
interface. This test article will be examıned to investigate life limiting hardware issues.

\section{Background}

The Fastrac engine was initially intended to be a booster engine for low cost expendable launch vehicles. A number of design approaches were taken to make the engine easier to produce to achieve the low cost objective. Primary among these was the use of simplified designs to enable tabrication with commercially available machining equipment. L'sing ablative nozzles provided a good solution to that problem. The Fastrac engine became the X-34 main propulsion system and final development was based on that application. A significant amount of the hardware design was essentially frozen. and redesign in increase the reusability would have adversely impacted the cost and schedule of the engine. The Fastrac ablative nozzles are designed for a 300 see hurn duration. or a $\therefore$ se engine aceptance test and a fuil duratron i is ac) burn during a $X-34$ mission. It is a 30 ) ! exmansion ratio nozzle, but the nozzles are ofien truncated at 15:1 for sea level development testing. The Fastrac engine perates all a chamber pressure if 1,33 posal and produces 60.000 lh. vacuum thrust.

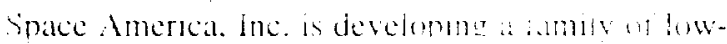
wh commercal rocket soncles molume wunding axkets. mititary tares vehickes. and fint and medium - latss expendable launcin vehictes. Cerenerallvely

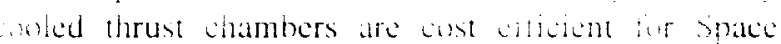
Americass main propulsion wsiems hy allowing atdional development testme athoul havmes at

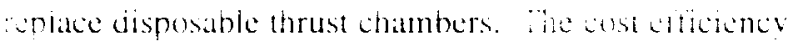
nereases it the vehicle or stage is recovered

SAI began evolutumarv devefopment if ereneratively-cosled lox/herosene roshet engnes at the $4000 \mathrm{lb}$, thrust level with partially-cooled thrust thambers. The $t K$ engines provided aluable experience and test data and led to development of a $12,000 \mathrm{lb}$, regeneratively-cooled engine. The $12 \mathrm{~K}$ engine is fully regeneratively-cooled, using copper tubes hydratormed and shaped to fit together to form the nozzle and chamber contour. The graphite structural overwrap approach that had been entirely successful at the $4 \mathrm{~K}$ level was maintained. A test apparatus was built to develop and prototype the netshape hydratorming process. Figure 1 shows the chamber during assembly (photo on the left is the tubewall assembly partially welded. and the photo on the right is the fully assembled chamber after application of the graphite reinforced composite overwrap jacket).

\section{Application to Fastrac Engine}

A regeneratively-cooled thrust chamber can benefit the Fastrac engine development program in many ways. It allows increased development testing without the me and expense at replacing ablative nozzles. Regeneratively-cooled engines are generally expected (1) provide approximately $1 \%$ increased performance, athough the counteracting real processes inside the smbustion chamber may tend (1) dissipate that theoretcal increase. In the $\mathrm{X}-3+\mathrm{t}$ program. or any usable vehicle. a regeneraturely-cooled engine also iecreases program cost. whedule. wh risk by timinatung the requarement (1) install a new nozzle after ach mission

\section{Program Philosophy and Approach}

in ageressive schedule was extablished in order to roduce test hardware for an anticipated lest stand wailabitity approximately o monins from contract start. Soncurrent design practices were utalized to enable the fesign 10 progress based upon lirst-order calculations while higher-order analyses were being developed independently by consultants - when the higher order

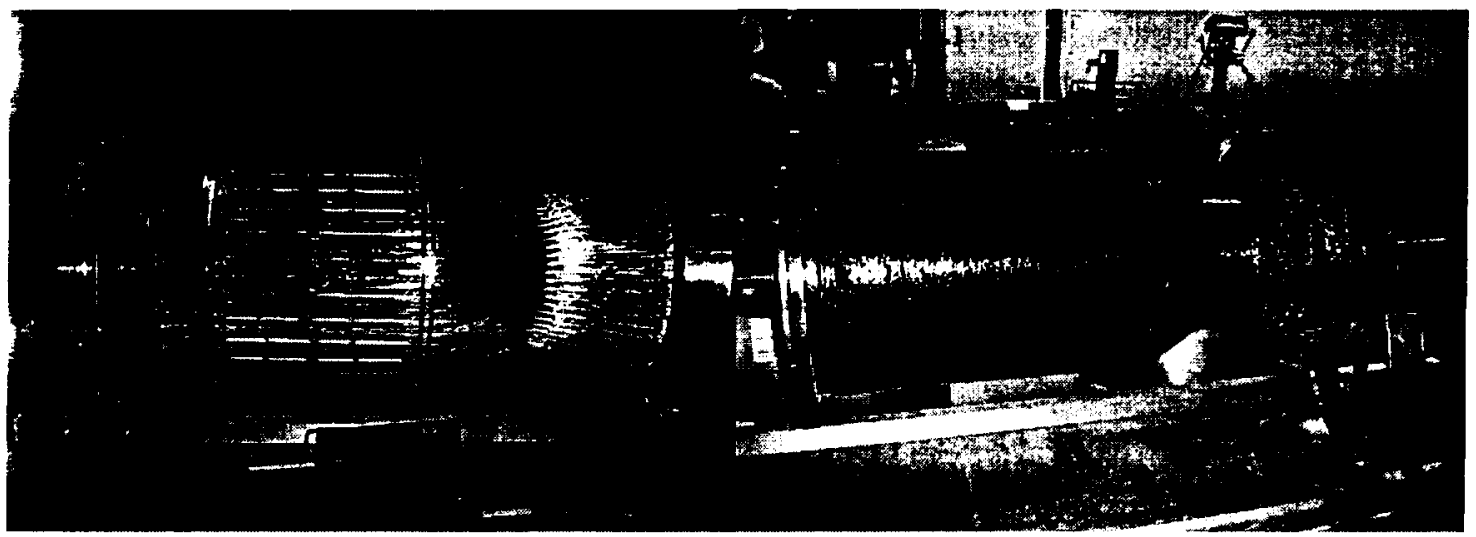

Figure I - Space America 12K Regen-Cooled Lox/Kerosene Engine

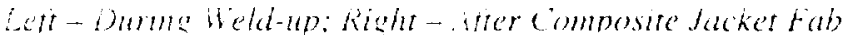


analyses were obtained, that information was incorporated into the hardware design. The program was planned with four primary tasks: preliminary design, detailed design, fabrication, and lesting. Reviews were held with MSFC at key milestones in the program.

Initially, the preliminary design tocused on key areas of technical risk. A primary objective of this program was to demonstrate that fabrication of a regeneratively cooled Fastrac thrust chamber can be an economical alternative to the current ablative chambers. Therefore, the proof-of-concept test articie needed to be representative of any eventual tlight units. This presented a number of contlicting requirements. principally, the ability to design the chamber for lesting as a thrust chamber assembly while maintainine the thility to integrate it into the engine system. The cure concern was the ability to develon desiens and abrication processes for the manuracture of a smele

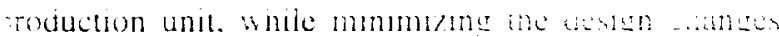
aceded for increased production.

The Space America, inc. 12.000 ibt rocket enente perates at 250 psia chamber pressure and $i$ eqeneratave-cooled to an area rato bi anproximalew

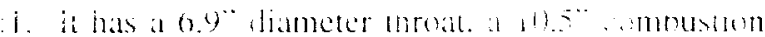

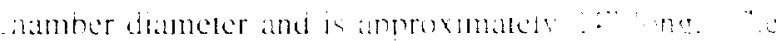

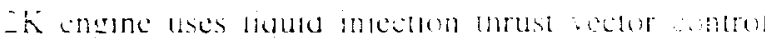
and the side fored the compostle lated nust carrs a

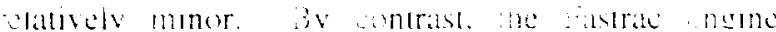

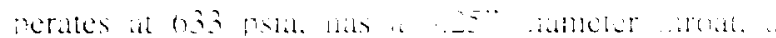
$1.282 \%$ combustion chamber diameler. and the $=4$ rea ratio nozrle is anproxmatch +- " tne "ho

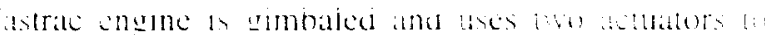

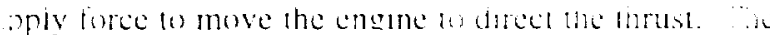

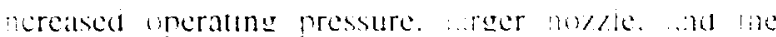

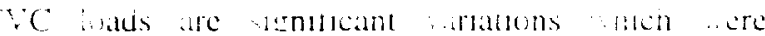
:ddressed during the design. Additionallv. SAI centitied hat the larerer norkte necesstated the use al a

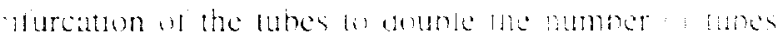

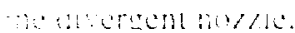

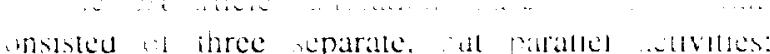
abricating subcomponent and assembly coling. abricating the hydratormed tubes, and labricating the manifold parts. Throughout tabrication of the test article parts, inspections and tests were conducted in

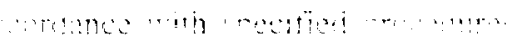

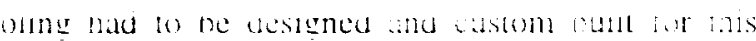
roject. partly due to the physical difference hetween he Fastrac chamber and space smerica: $2 \mathrm{~K}$ wane and partly to solve problems identified during abrication of the $12 \mathrm{~K}$ chamber. Fabrication tooling

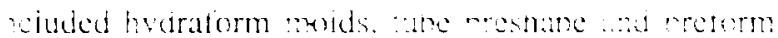

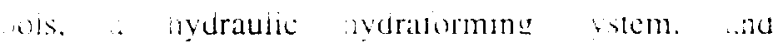

miscellaneous alignment and fixturing tools. The assembly tools included a horizontal assembly cart, a vertical assembly pallet, an assembly mandrel, and miscellaneous alignment and fixturing tools.

\section{Design}

The preliminary design effort defined the functional requirements, updated the conceptual designs, and reevaluated proposed manufacturing lechniques. The contract required fabrication of a single thrust chamber for design verification testing. Fabrication of additional regenerative thrust chambers is highly uncertain, and depends upon the performance of the component during testing and upon the direction of the MC-1 engine and X-34 programs. Thus, design and fabrication approaches were reviewed during the preiminary design effort to determine the optimum approach for tabrication of the lest article, and to define reas that could and would he improved if production the reren-inrust comamers was neaded. This section ill present the derived reyuirements for design of the ist articte. design rade studies. and integrated engine oncepts.

\section{esign Requarements}

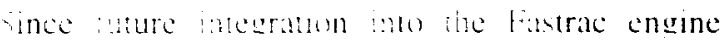
semoly is the nurpose at ats develonment. defining te mortaces bats the litst prority. Two sets of meraces and desten reutrements exist - lirst for the

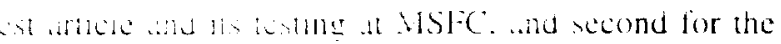
mesration of a resen-chaminer into the Fastrac engine nsembly seral trade sudies were performed. scluding abes, stermane ac ded line mbiraraton. he contant carcuit lone-pass or pass-and-

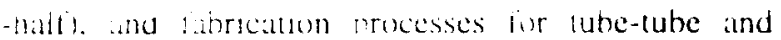
atewal-manubled fomm and the composite jacket.

The coolant tubes must be primed with fuel prior to carting the man combustion chamber. The life of a

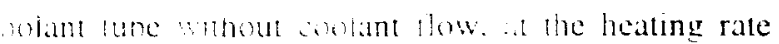

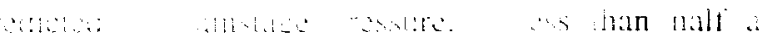

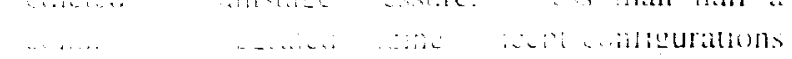

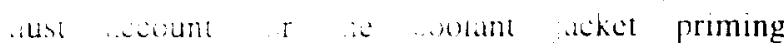
equirement.

The test articie structural jacket was structurally designed for the currently predicted Propulsion Test Article and $X-34$ thrust vector control actuator loading

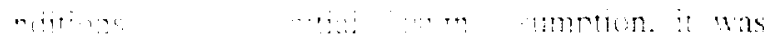
stumed that the composta ladret wold be designed to carry all of the actuator loads.

The haste anproacin 11 dievelonne concepts for integrating a regeneratively-cooled thrust chamber into the Fastrac engine assumes the major components stay be sume. and most in the same rositions. but all of the condary amponents an ren ratranged. Irying to 
create a regen thrust chamber as a line replacement unit and interchangeable with the ablative nozzle seemed to be unrealistic. In effect. this produces two different Fastrac engines - a regeneratively cooled Fastrac and an ablative Fastrac. with the only difference between the two engines being the thrust chamber and the size of the fuel orifice. The engine must have a horizontal start capability, i.e. use in the X-34, so consideration of the coolant jacket priming is essential. Relocation of the main fuel valve became essential to integration concept development. The governing assumptions and ground rules for the new fuel flowpath in the regen-engine are the following:

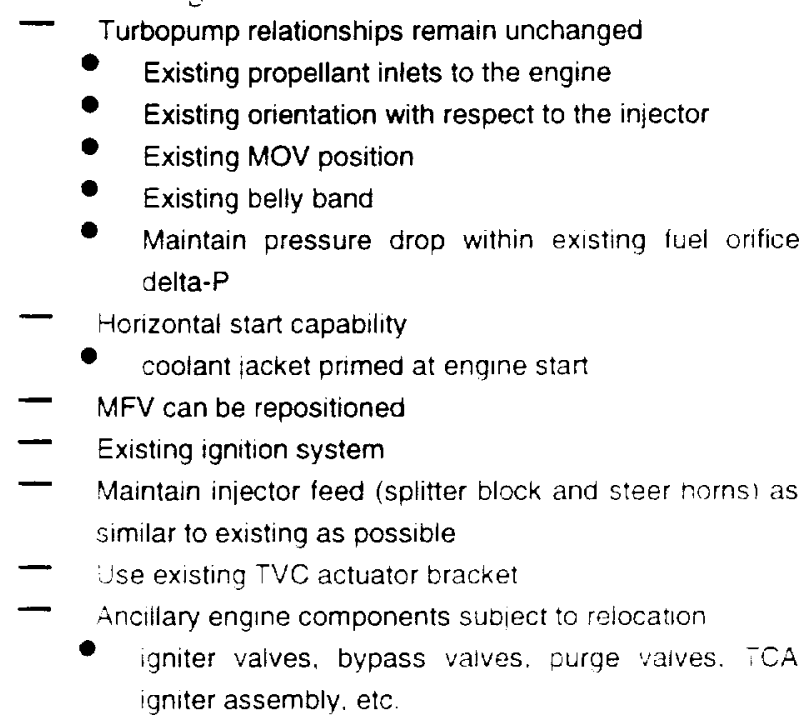

\section{Integrated Engine Concepts}

To demonstrate how the regeneratively-conled thrust chamber can integrate into the engine system to provide a regeneratively cooled Fastrac engene. a couple of conceptual lavouts were develoned. I concept was developed for an altitude engine with a 30: 1 expansion ratio nozzle. such as the X-34. and for a hooster vehicle application. The conceptual lavouts nly show the major engine components - regen thrust

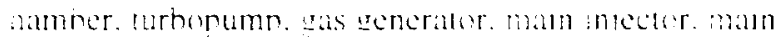

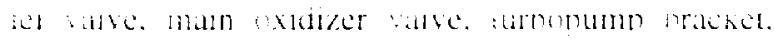
IVC actuator bracket. lox feed line. and tuel teed line.

\section{X-34 Application}

Figure 2 shows a conceptual model of $a$ regeneratively cooled Fastrac engine suitable for the $\mathrm{X}$ -

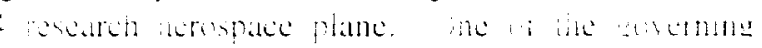
design requirements was the ability to have the coolant jacket fully primed at engine start. thus the coolant lacket needed to be between the luel turbopump discharge and the main fuel valve. As part of the X-34 mission profile the vehicle is carried at an altitude of $-5 .(6)$ fit for about ar hour prior to drop and cingne

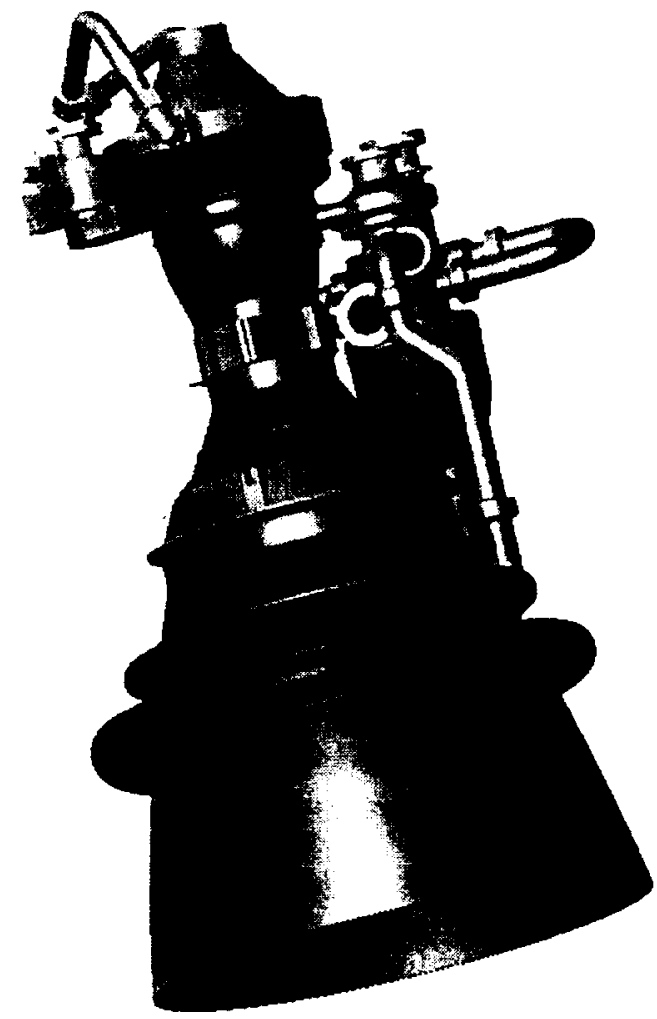

\section{Fisure 2 - Fastrac Engine with Regen-Cooled Thrust Chamber for X-34 Application}

isnition. The ambient temperature at that altitude is near the freezing temperature of RP-1. thus a major yystem integration study will have to address that issue.

The MFV is moved to the opposite side of engine, moved up. and uses the same splitter block arrangement as the existing engine to distribute fuel to the two sides if the injector. The engine system is shown with a nozzle extension to provide the $30: 1$ expansion ratio nozzle. The thrust chamber is regeneratively-cooled to an area ratio of $15: 1$ and nozzle skirt is connected to a tance included as nart of the lower fuel manifold.

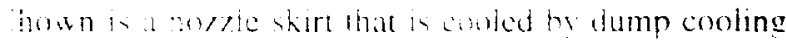
:t ramspratuon cooling wh the gats generator exhaust. similar to that used on the Saturn $F-1$ engines. An ablative nozzle extension or an uncooled refractory metal nozzle could also be used. The low heating rate in that portion of the nozzle would allow a properly designed ablative nozzle extension to have a life of

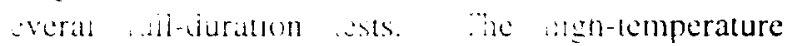
refractory metal nozzle extension probably would not be a good choice for the X-34 application because of the radiative heating load generated to the aft section of the vehicle. 


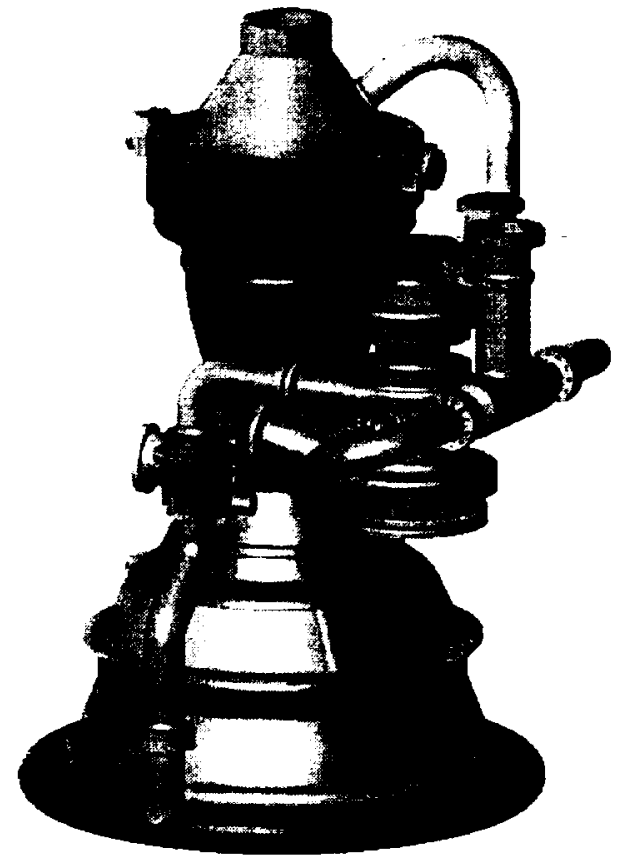

Figure 3 - Fastrac Engine with Regen Finnst Chamber for Booster Anplicatom

Emiter Anpizintoms

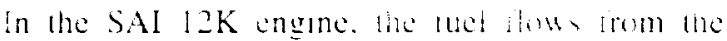
apper mantold directly into the meeter tued mantoh. aus avolding piping to connect the upper fued mambud a the mector. If it ts atsismed the rastrate engne as arted in a bertical contiguration. is in a certical

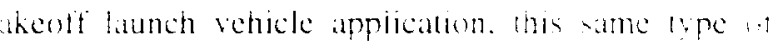
stem can he used. The wontant lathel suld in manually pre-primed, or the start sequence modified to fill the jacket as part of the start transient.

Figure 3 shows a conceptual layout for a booster application Regen-Fastrac engine. The fuel pump discharge is connected to the main fuel valve, which is rotated down $180^{\circ}$ from its current configuration. The MFV feeds the lower manifold. The upper manifold feeds the injector directly through holes or slots in the thrust chamber flange and the injector. The concept model is shown with the 15:1 nozzle used for the test article design. The exact nozzle contour would have to be optimized for the specific booster vehicle application, but that has relatively minor implications on the hardware design.

\section{Design Description}

Figure $t$ is a CADD model of the regen thrust chamber test article. The coolant jacket is fabricated by welding hydratormed copper tubes together to form a continuous tubewall. The regen thrust chamber contour is the same as the existing ablative nozzles - with one exception - the straight segment in the throat has been removed. A straight throat sectoon is often used in ablative throats. but is unnecessars in a hardwall chamber. The major components 11 the assembly andude the lubewall. the lower and apner manitolds. and lhe composite structural lacket.

Copper luning, diloy C.122, is mydraformed to btan the correct widths at all axial positions along the urust chamoer contour to prouuce a contmuous coolant lacket. It is formed using two sets of tuhes: the first set omprise the combustion chamber and norgle section to

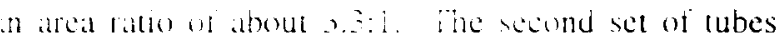
rm the nusfe from the $\therefore . .1$ in $5: 1$ area ratios and

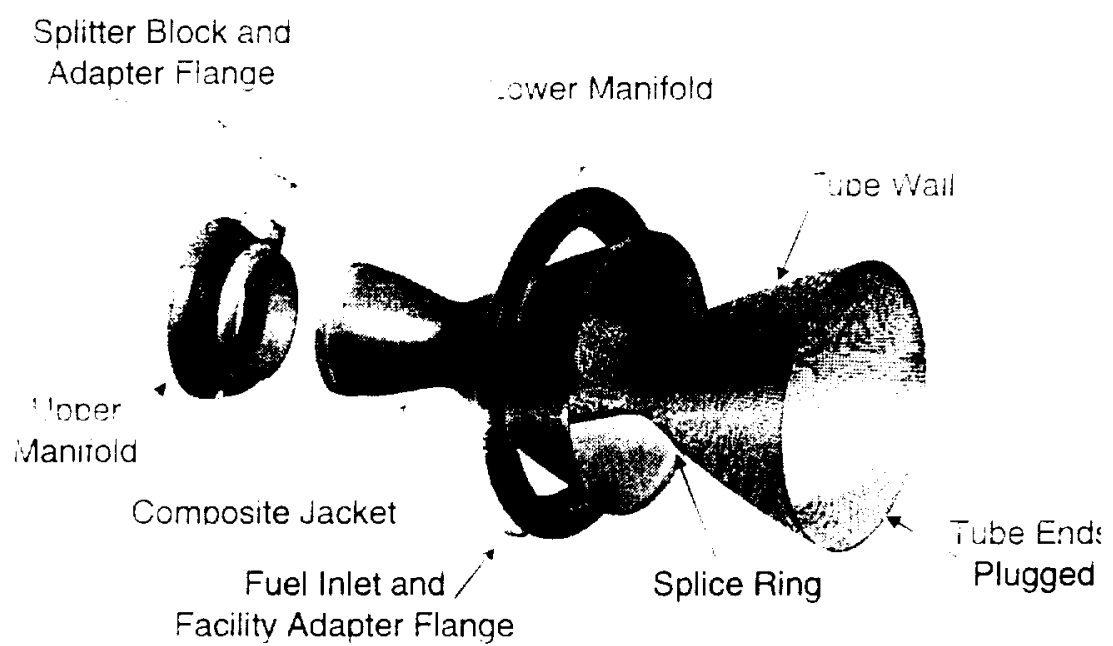

Figure $4-$ Exploded View of Thrust Chamber 
contain twice as many tubes as the chamberithroat tubes. A machined copper ring with pass-through slots is used to take the coolant flow from two nozzle ubes into one chamber/throat tube.

The fuel enters the thrust chamber at the nozzic exit with a single inlet duct. The inlet manifold, a toroid formed by rolling a piece of stainless steel tubing, distributes fuel to each tube through a slot in the top of each tube. The torroid is attached 10 rings weided to the tubewall, and the upper support ring serves as a transition to the composite jicket. The upper manifold contains the thrust chamber flange in attach to the injector. The injector intertace design is exactly the same as the ablative design, with particular attention to ensuring the aperture to the injector acoustic cavity is the same. Fuel exits each tube through a slot in the top of each tube to the mannold. The upper manifold exit is located $180^{\circ}$ from the inlet in provide as equal thow as possible through each wabe.

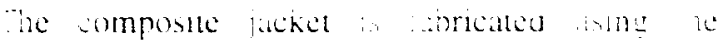
involute labrication process. discussed in ane next ection. A grapnite/phenolic preimpregnated tabric was celected due to the predicted temperature in the amposite/tubewall interiace.

\section{abricitum Process Selection}

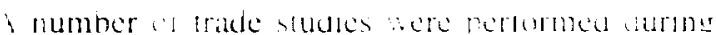

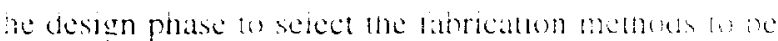
sed on the test artucte.

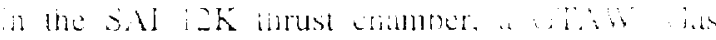

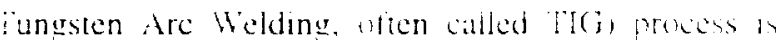
thed to foin the tuhes to form the tuhe wall and a a bot

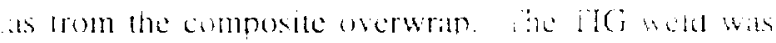
red hecause al problems wah a siver-solder pame an

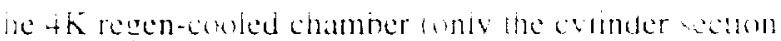
i hat chamber was cooleds. she a corch-brace requires heating a much larger area. creating difterential hermal expansion. contamonatuon proviems atume the aring of the composite wket ato arsinte

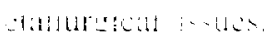

$$
\text { in: }
$$

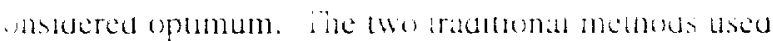
o join coolant tubes for rocket engune thrust chambers re lurnace brazing and electroplating.

Alter reviewing the specifications for furnace brazing alloys, we determined that furnace brazing

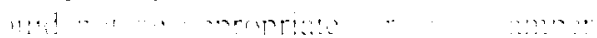

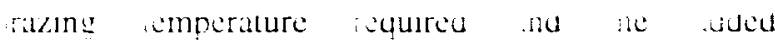
ecourements of the assembly tooling.

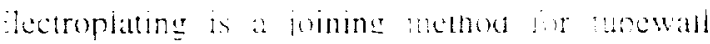
engines, and is used on SSME. Ariane $V$. and numerous ) ther rocket engines, and seemed like a reasonable

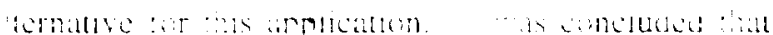
accoroptating sould be an excetien candidate bor at production run of regen-chambers, however for a oneunit production the non-recurring engineering and tooling costs were prohibitive.

The SAI 12K engine has a graphite composite materiai structural jacket fabricated on top of the tubewall and tied into the upper manifold. The SAI $12 \mathrm{~K}$ uses a liquid injection thrust vector control system. so the side force. and resulting bending moment, that the jacket must resist is small. The primary load the jacket must contain is the combustion chamber hoop stress. A composite jacket was proposed for the Fastrac chamber using an involute fabrication method. An involute composite lay-up is often used for ablative solid propellant rocket motor nozzles, so extension of the method to this application is somewhat unique. An aternative identified in the proposal was to fabricate he structurai jacket by electroplating nickel on top of the tubes.

in intolute lay-up technique means that a umoste part is iabricaled using indiviciual panels of . mposite labric latd on top of each other. aach offset y some amount. One can envision an involute by aking a deck of cards and spreading it out on the table sth each card offset paralled to each other by a set mount. Then take the cards and hend them around a ranutred and nek the und the enread out cards

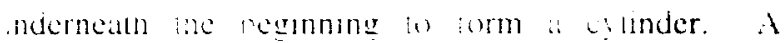
imposile lackel can similariy be labracated tor a rocket neme by latkine axal strins and mujviduably forming

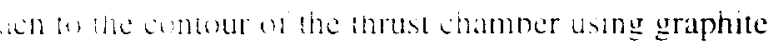
ber labric pre-impresnated with resin. In involute

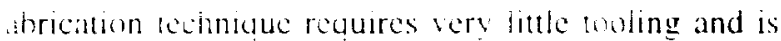
a excellent andon tor probotypiner.

- testern made tudy was develoned to weigh bricatom at the composite ixited wath in involute whet iersus the more conventional meonod winding or tiber placement. The review determined three critical isadvantages os the conventional method. First. in vier fo use a wandine mathine for the comnosite jacket

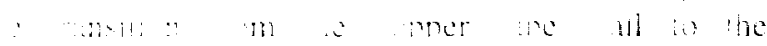

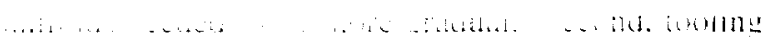
butd be needed at the nokzle ext and the injector atertace flange to allow the fibers to wrap around the ands (material which would be later eut offi. and this tooling would be large and could be outside the costs hudgeted for composite jacket tooling. Finally, the

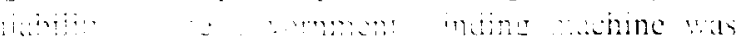

uniec w the prioritues of the government s use, and as uch. coude create a schedule problem affecting test aticie telivery. The primary avantage the tiber winding machine is that the jacket would be applied in asentially the same design as the existing ablative

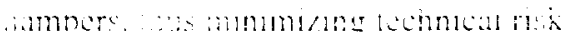


The third alternative evaluated for the structural jacket was electroplating a nickel jacket on top of the tubewall. Nickel offers a high strength, high modulus material and brackets could easily be added by welding them directly to the nickel. The attractiveness of the nickel jacket exists only if the tubes are joined by electroplating. Once it was determined that electroplating the tubewall was prohibitively expensive, a more detailed investigation of the nickel jacket was abandoned. Issues which need further investigation are differential thermal expansion and the resulting thermal stresses, and crack propagation caused by the preferential grain growth direction.

\section{Prototyping}

A number of prototyping activities occurred during the design phase in order to completely understand the processes required for fabrication. All processes were prototyped which were significantly different than used in the $12 \mathrm{~K}$ thrust chamber, or where the process used in the $12 \mathrm{~K}$ thrust chamber could he improved. Prototyping was conducted in three areas, tube welding and brazing, tube hydraiorming, and composite jacket fabrication.

\section{Design Analyses}

Fluid dynamic and structural analyses tvere conducted as needed to support the lest articie design and to predict the performance of the hardware. Lower order calculations and analyses. empirically hased and simple analytical equations, were generated to begin the design while higher order analyses were being developed. Computational tluid dynamic analysis of the llow through an individual tube was conducted to wbtain a higher resolution of the tluid hehavior in the individual tubes. Finite element method structural analysis software was used to support the mechanical design of the test article.

\section{luid Dymamic Analysis}

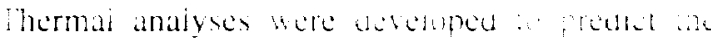
lemperature at the tubewall-composite jacket intertace. the bulk temperature rise in the fuel. and the coolant circuit pressure drop. The analyses were anchored against test data from the SAI $12 \mathrm{~K}$ thrust chamber. A hot-gas side prediction was made using the Bartz uation. with correlations of the $12 \mathrm{~K}$ tala and is hown in Figure 5.

A 2-D transient model was developed to predict the heat transter in and through the copper tube. The transient analysis shows that the engine reaches thermal steady-state after 2 seconds of mainstage operation (the -imulation ignored the engine start transient). Figure 6 is a plot of the temperature distribution through the tube

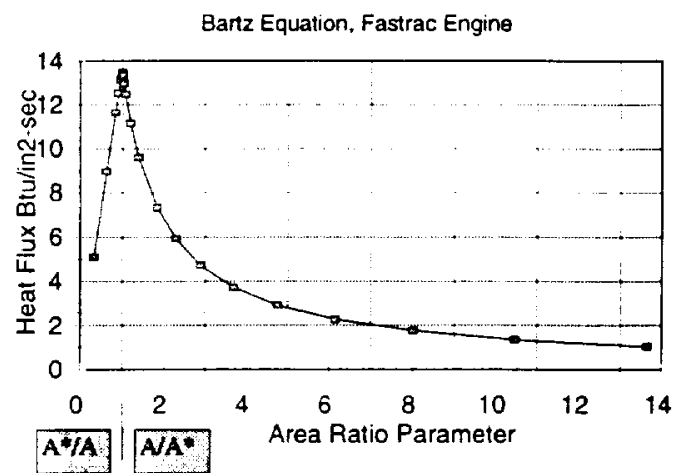

Figure 5 - Predicted Heat Flux for Fastrac Engine

wall as a function of the position along the tube from the center of the tube inside the chamber to the center of the tube at the interface to the composite jacket. This plot shows the predicted temperature across the tube is approximately $70^{\circ} \mathrm{F}$. It also shows that the temperature at the composite jacket interface is approximately $260^{\circ} \mathrm{F}$. The heat conduction through the tube and predicted inside wall temperature is used with a liquidside convection model to predict the temperature rise in the fuel coolant. The predicted bulk temperature rise is approximately $160^{\circ} \mathrm{F}$. A pipe-flow, friction factor method was used to predict a 22 psid pressure drop in the coolan tuhes minus the inled and exit effects.

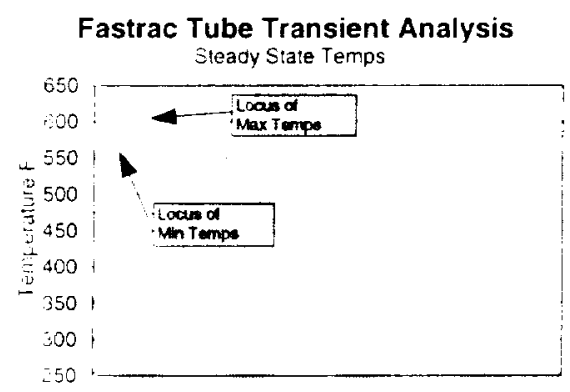

\section{Figure 6-Coolant Tube Temperature Profile at the Throat}

The somnutationat Thei armam a CFD) model mmulated the liow an aach of the lunes. but not the inlet, exit, or the tube splice ring. The CFD study included the effects of variable properties (density, viscosity, specific heat, etc., as a function of temperature) and used predicted tube wall temperatures generated by the analytical models. The CFD results correlated very wetl. predicting a lulat cmperature rise of $158^{\circ} \mathrm{F}$ and a pressure drop of 24 psid. The CFD analysis modeled the boundary layer of the flow at the hot wall and determined that the conditions required for coking of the RP-I propellant do not exit. 
Structural Design and Analysis

As with the fluid dynamic analyses, the structural analyses were conducted in two phases. initial hand calculations and low-fidelity finite element method (FEM) models were used to size the hardware while more detailed FEM models were being developed. The structural jacket design requirements were based upon the loads from an integrated engine with maximum TVC actuator loads. Problems with developing the detailed FEM model prevented having the final result until after the detailed design was complete. As will be discussed, the final FEM analysis indicates the test article has sufficient structural margin for engine testing, but may not be able to support the predicted TVC actuator loads. The composite jacket was sized using the initial assumption that the jacket carried all of the combustion chamber pressure and maximum predicted TVC actuator loads. The predicted TVC actuator loads are quite high and include neak Jvnamic i)ads as static loads - a conservatuve assumption. Cing endor data for typical graphite/epoxy amposite materials, a conservative design was chosen o provide " wall thickness of 0.25 " in the combustion chamber ind through the TVC actuator postion on the nomble. Bevond the TVC actuator the design thickness was

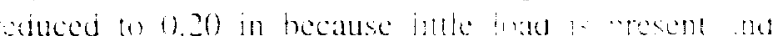
urther mokness reduction andid sate aed a manutacturing problem.

The cross-sectional geometries of the cowatn anes

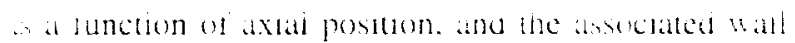
hicknesses. were developed using the low-ievel FF. blware. The analysis was validated arams the

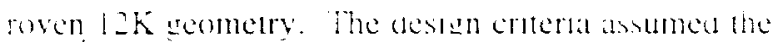
inper lubing had fully annealed srengen properass. ven though a sienificant. hut warkbie amount of entedcorking is present in the tubes anter the nydratormng. Thus. any grain growth. and subsequent reannealing. aused by the heat introduced durine the asembiv coding is essentally irrelevant. The 2 D transent neal

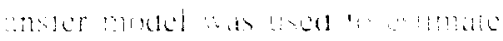

$=020$.

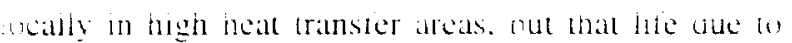
thermal eycle fatigue is of the order af 100 eveles starts to mainstage).

The detailed model included the internat chamber pressure, the internal tube pressure. and the TVC

aulviual tubes. the weids. ane spltce nne. and the composite jacket were limited by the soltware. A piane isymmetry down the center of the thrust chamber was defined and half of the chamber was modeled. Initial results of the model seemed to confirm the initial

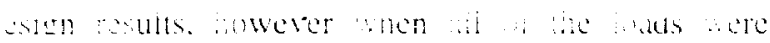
combined. and the mesning problems solved. the model predicted negative margins in the tubes in the divergent portion of the nozzle between the splice ring and the throat. The final model included updated property data for the graphite-phenolic jacket. Since the stiffness modulus for the composite jacket is less that the stiffness of the tubewall, the bending moment from applying the TVC actuator load is restrained by the tubing instead of the jacket.

When the graphite-phenolic fabric was received, tensile test articles were designed and fabricated in an attempt to gather property data for the involute jacket. Two tensile test samples were designed - one to obtain the bond strength between the jacket and the upper manifold and the other to obtain the bulk tensile strength in the as-laid configuration. The bond test specimen provided results representative of the matrix heing used. However. the tensile test specimen data vals inconclusive due to insulficient fiber length.

Composite materials experts at MSFC were onsulted lo review the tensile test data and its impact in the involute jacket design. It was determined that without significant additional testing, the involute acket may not he able 10 support the design eouirements. However. since structural testing with Ye actuator loads was not in the lest plan. and since

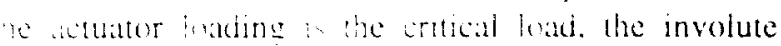
atet was redesigned using updated design criteria and isslened for the meernal chamber pressure as the ritical load. The test oniectives for the test article can thl he met with the ciamner. however the design had b) he lurther iterated to aceount for fabrication issues.

The negative marem predicted in the tubewall as a sult of the lubewall. place ring. and composite jacket icsien indicate the tructurai design needs to be unticantly readdressed as a dollow-1)n project.

\section{Fabrication}

Snecial woling had to be fabricated for the tube mone and thamner astemnly the lo lhe significant

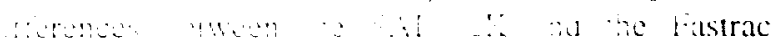

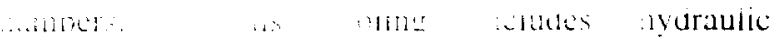
Iyuratormıng aupupment, a segmented assembly mandrel, and miscellaneous assembly fixtures.

The assembly mandrel and horizontal assembly curt is shown in Figure 7. The sections in the combustion chamber. the convergent nozzle throat. and

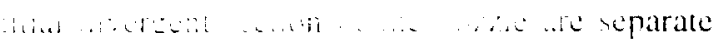
arts fabricaled from low-carbon sted. The remaining cecuon of the nozzle was fabricated by applying a thin aver if low-carbon scel un lop if a special polyurethane foam and metal structure. The foam was machined undersized to the desired contour and the

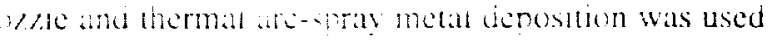
(1) build up a steel shell to the linal dimension. The 


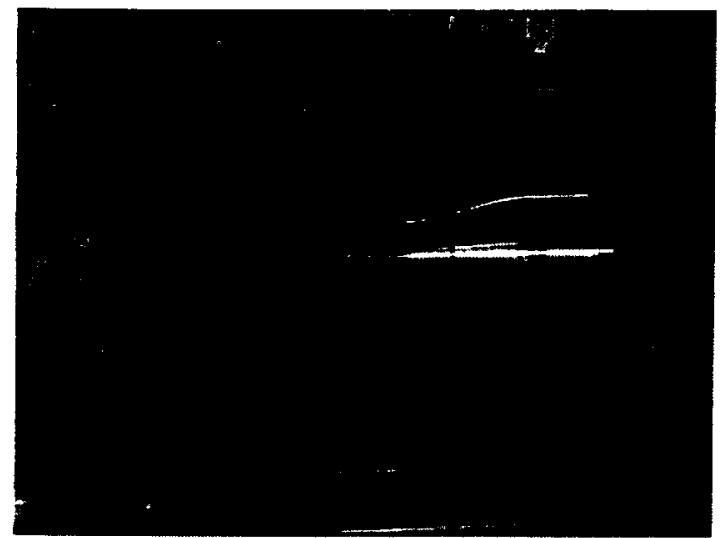

Figure 7 - Thrust Chamber Assembly Mandrel

fabrication process for the nozzle mandrel was ignificantly less expensive. than building it by rolling und machining steel plate. There was also the added venetit of lower weight and easier 6 handing.

Each of the two tube sections were fabreated using - nydratorming process develoned hy snace smerica. anc. for their commercial propulsion ssems. ilter each tube was formed to the final shape it was inspected for defects and dimensions. An enci plug was (TTAW seved into each tube and proof tested to anroymatedy $30 \%$ of the nominal operaune presure incles the whe.

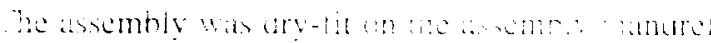
not the tit in the crutical regums at the ammusuon

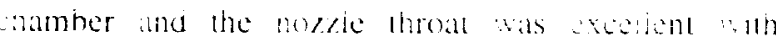

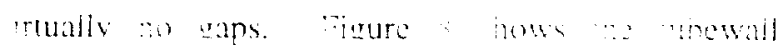
asemnly durng dry-1tt.

GTAW was selected lor the iunewal solding

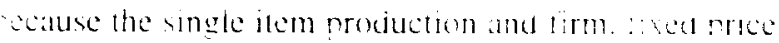
ontrate preciuded development of the electrobating ther joining process. Dooxidized cunper tilter rod was

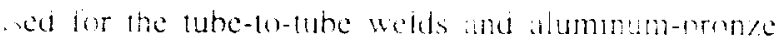
iller rod wals used to joun the copper tudewall to the tainless steel manifolds. During welding of the nozzle sme of the tubes were werneated bhat on turn

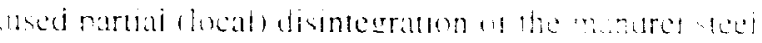

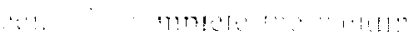

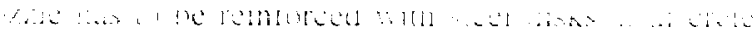
wial locauns. This lett unsupported gaps netween the isks. which compromised the desired amensional -) Jerances of the nozzle.

Torch brazing was selected for joining the tubes to the snlice ring. A silver-hearing hraze filler rod was

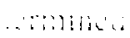

npilication. Prototype braze fant lests muleated the rint design would allow the hraze materna th how sween the adjacent lubes and provide a sirong fom with no leakage. After brazing of the splice ring tubes. cienificant amount of repair had to he ande. und

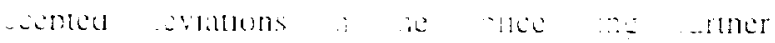

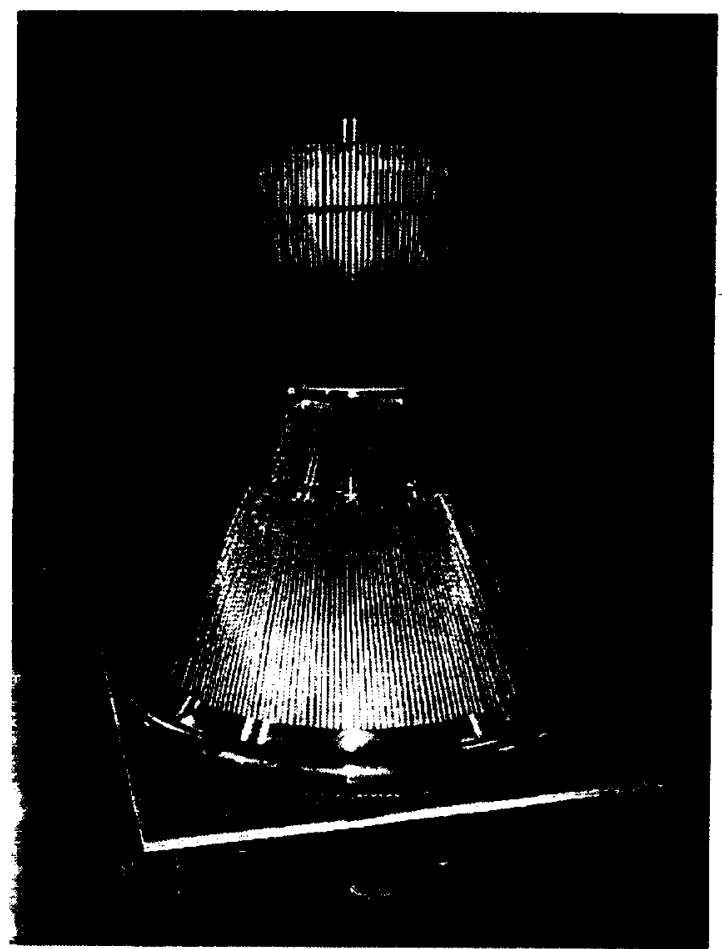

Figure 8 Dry-fit of Tubewall Prior on Welding

vacerbated the brazing. The resulting braze joint is

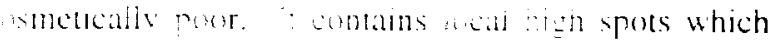
hay gencrate mall disturnances in the nozzle tlow. awever they ate not expected in senerate shock aduced hot-snols.

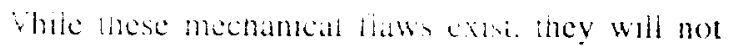
Hect meetng the test obiectives for the thrust chamber and are malur lessons barned hor-moseduent chambers.

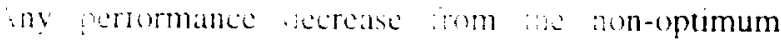
ande hane sould be monor. hut strust cannot be hatsured at the kest theility. of the :ertormance loss annoe be delermaned.

The original composite jacket design used fabric reces cut on the hias with respect to the ther direction.

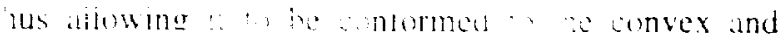

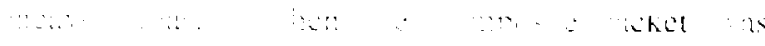

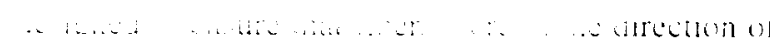
a houp stress in the combustlon chamber - the averning foad for the test article - the anvolute design hatd to be modified to buid up the inroat region to reduce the amount of contour change. Figure 9 shows the chamber during fabrication of the involute jacket. as inur tis

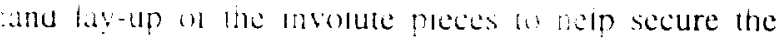
peces during the lay-up and to help hond the jacket to a kovwall. +t Thermocouples diud stran gages were attached to the metal tubewall prior to applying the resin and involute lav-up to nrovide cest data during it $-1,2$. 


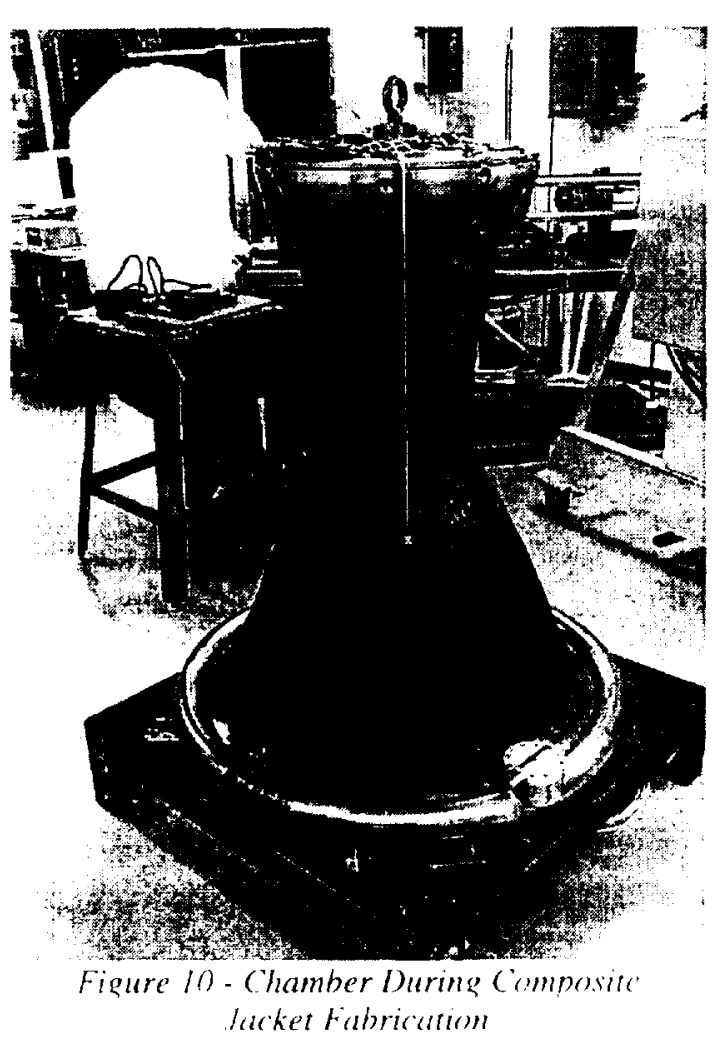

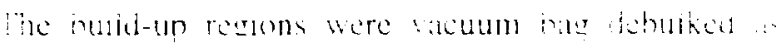
avers were applied and the tinal invorute assemnit was cebulked pros w the vacum bas cure cucke

The completed thrust chamber a down in Firure

Ho shown is the upper manmoli enow nisk and the tuel adapter block.

\section{Design/Process Improvements and Future iVork}

Benending upon future applications of the Fastrac ngine. and the need lo like stivantage at the egeneratuely cooled thrust chamber. atew remainng issues must be worked before tabrication of additional hrust chambers can begin. Lessons karned during the abrication of the cest article invicate that destem and

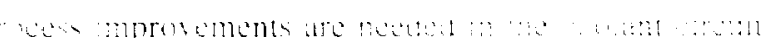

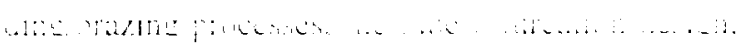

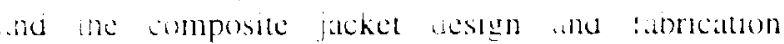
process.

While the test article was not designed to be a light weight test article, it is approximately the same weight as the 15:1 ablative nozzle. The design of the upper algnt. and opumizang the tube wonne process and composite jacket fabrication would also save weight. mservatucly a light-wetght ission at the regen thrust could save $10 \%-20 \%$ of the weight of the iblative nozzle.

\section{Design Improvement Areas}

A laser brazing technique for joining the tubes has been experimented with, and appears promising. This process could significantly improve the time associated with the coolant circuit fabrication. Since the involute composite jacket design does not appear to have adequate strength, a new design and associated fabrication technique is needed.

The bifurcation joint must be redesigned due to the problems encountered during the brazing. The major problem was the ability to machine a large piece of copper into a small, relatively low mass part. It became difficuit to control, and copper is notoriously hard to machine because as it is cut with the machine tool it becomes dimensionally unstable. A second problem with the current splice ring design was the difficulty in sealing the vertical intratube leakage, i.e. the leakage between the vertical sections of two tubes. Here, the iorch braze material could not tlow together from the up anu bottom to form is good scal. ironically, this nroblem was a result of the tubes fitting together too well.

\section{inulure Work}

At this rime. there are no plans to integrate a aneratively-conted thrust chamber into the MC-1 ngine as the propulsion system for the K-it. A regen hrust chamber could reduce program risk by

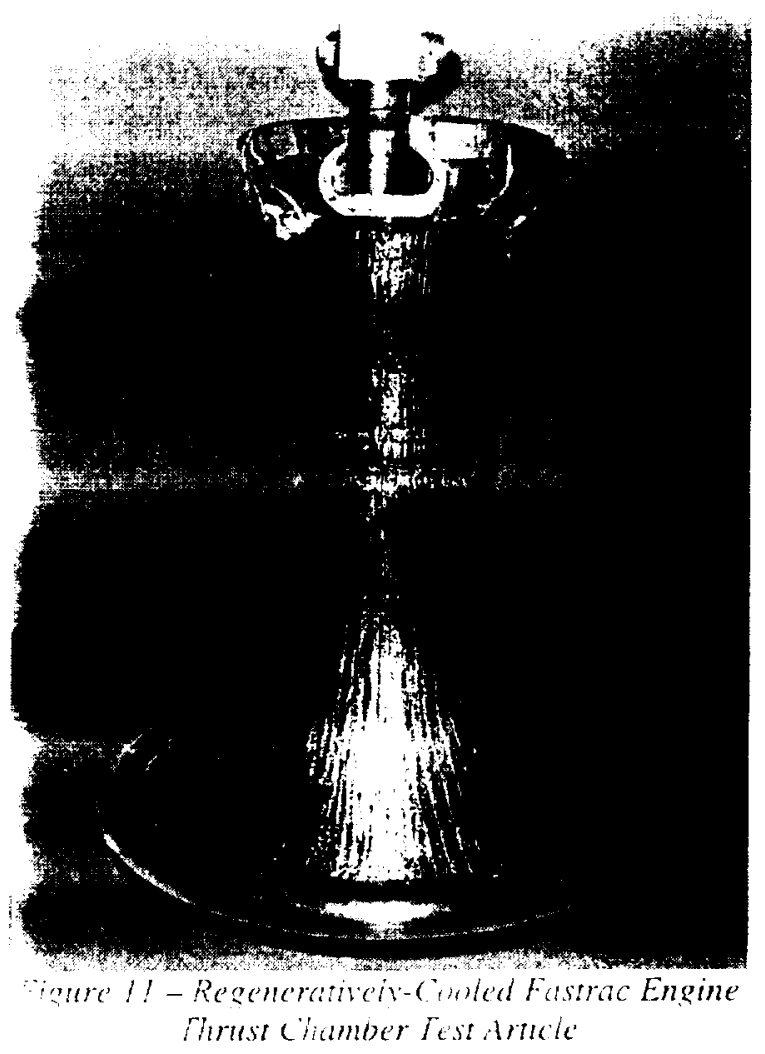


eliminating the need to replace thrust chambers after each flight. A comprehensive development program is needed to develop the technology and design to produce an integrated regeneratively cooled Fastrac engine. The path is defined by four major steps; thrust chamber process improvements, detailed integration layout, detailed integration design, and component and engine testing.

\section{Test Article Testing}

Tests are expected to be conducted at MSFC's test facility in October 2000, depending on test stand availability and MSFC priorities. The test objectives are:

- To demonstrate integrity of the test article and assess practicality of upgrading the Fastrac engine to a fully reusable engine by incorporating a regeneratively cooled thrust chamber into the design.

- To determine pressure drops in the fuel circuit and therefore assess ease of integrating the regeneratively cooled chamber into the Fastrac engine and power balance. Overall pressure drop in the fuel circuit is estimated to be less than the pressure drop in the current calibration orifice between the fuel pump discharge and the injector.

- To compare measured temperatures on the combustion chamber structure with analytical predictions. to confirm predicted temperatures and heat transfer rates, and to assess cooling margin for the regeneratively cooled chamber.

The chamber wall is instrumented with tl thermocouples attached w the rutside of the cupper tube wall. These were installed before the werwrap was put on the chamber. Thermocouple probes are licated in the fuel inlet and outet manitolds to measure bulk fuel temperature rise in the cooling jacket. Pressure taps are located on the fuel inlet and outlet manifolds. in the injector. and located in the thrust

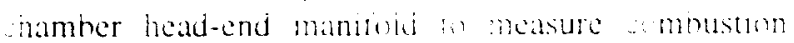

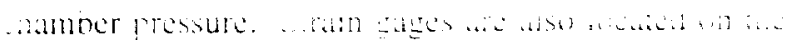
lubewall.

All hot-fire tests will use the standard start sequence for a component-level. thrust chamber assembly test. Following checkouts, three hot-tire tests are planned:

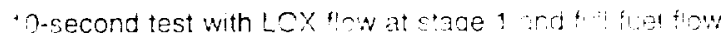

In this condition. the LOX ilow is metered by the LOX

valve and the fuel flow is metered by the facility cavitating

venturis. Chamber pressure is predicted to reach about 400 psia.

- 30-second mainstage test, targeting nominal chamber pressure 633 psia.
- 150-second (full duration) mainstage test, targeting the same condition.

\section{Summary}

A low-cost regeneratively-cooled thrust chamber has been developed for the Fastrac engine, and a proof of concept test article is awaiting test stand availability. The cost of the regen chamber is expected to be approximately 2.5 to 3.5 times the cost of the current ablative nozzles, but it is expected to have at least 3 times the life. The exact cost is difficult to determine until the identified process improvements are completed and a nozzle skirt designed. The future of the Fastrac engine and the Fastrac engine is unknown, so further development of this thrust chamber is unknown.

\section{Acknowledgements}

The authors would like to acknowledge the support if it's major subcontractors: Advanced Composite Technologies and Associates. Inc., Huntsville, AL; Microcraft, Inc, Huntsville, AL and Lacey's Spring, AL; Metal Research. Inc.. Guntersville. AL; Accurate Machine \& Tool, Inc.. Madison. AL: and Propulsion Research Center, University of Alabama in Huntsville, Huntsville. AL; and numerous reviewers in the Space Transporation Directorate and the Engineering Directorates at NASA/MSFC. 